\title{
INDONESIAN POST GRADUATE STUDENT'S MOTIVATION AS AN AUTONOMOUS LEARNER IN OVERSEAS UNIVERSITY
}

\author{
Dzikrina Mardhotila ${ }^{1}$ \\ Universitas Negeri Surabaya \\ Syafi'ul Anam \\ Universitas Negeri Surabaya \\ Slamet Setiawan ${ }^{3}$ \\ Universitas Negeri Surabaya \\ dotik059@gmail.com ${ }^{1}$ \\ Submit, 18-03-2020 Accepted, 13-06-2020 Publish, 14-06-2020
}

\begin{abstract}
This study investigates the motivation of Indonesian postgraduate student as an autonomous learner in overseas university. This study focuses on answering a research question; (1) how the learner motivates himself for being autonomous learner. The qualitative method was used to fulfill the objective of the study. The data was collected from interview section with the student. It was transcribed and analyzed descriptively. The result shows that the student is an autonomous learner who has intrinsic and extrinsic motivation in learning language in overseas university. It can conclude that this study will enrich the discussion which relates to students' motivation for being an autonomous learner especially in overseas university.
\end{abstract}

Keywords: Autonomous Learner, Motivation, Intrinsic and Extrinsic

\section{INTRODUCTION}

In recent years, many people talking about learner autonomy as a new model of learning. Being autonomous learners strengthen their responsibilities in study. This connects to their study purposes; it should be in line with what they will do to get their purposes. Additionally, the learner autonomy focuses on the ability to take responsibility for his learning (Benson, 2013)

Benson (2013) reviews on autonomy in foreign language learning from a philosophical perspective and also focuses on the importance of putting our perception of autonomy in language learning within wider definitions of autonomy in learning and autonomy in life. He noted that the recent concept of 
learner autonomy often includes increasingly psychological aspects of autonomy. Some autonomy proponents claim that if learners are to develop their autonomy, they need some degree of independence in learning. Furthermore, Autonomy can be seen as a learning method in which the learner can or is responsible for his or her own learning.

Learner autonomy in Indonesian EFL context marks as a individualism, self-regulation, motivation, and interdependence (Blidi, 2017). The main marks that can be seen in learner become autonomous learner is motivation. Learner autonomy and motivation is needed each other. As we know that motivation is no more seen as a reflection of definite internal forces such as instincts, volition, will, and psychic energy; it is considered as a feature of stimulation and strengthening in purely terms of behavioral. Motivation refers to the decisions made by people about what activities or goals that they will pursue or avoid and how much effort that they will make for this regard. Anjomshoa, \& Sadighi (2015) points out that general motivation theory seeks to explain no less than the basic issue of why people act as they do, and it would therefore be naive to suppose any easy and straight response. Anjomshoa \& Sadighi (2015) identify some factors as motivation promotion in language learning: attitudes, beliefs, goals, involvement, environmental support and also personal attitudes.

Several fields of general education motivation studies indicate that learner who takes responsibility for his own learning can be motivated to learn and learn more effectively. Also, many of these ideas are central to learner autonomy discussions. If we look at the definitions of learner autonomy, we can see that learner autonomy and motivation are sharing their certain key concepts for example, learner choice, and learner independence and also learner responsibility. Abuhamdeh, et.al (2015) work, a powerful connection between motivation and autonomy can be viewed as intrinsic motivation. They differentiate between intrinsic and extrinsic motivation; those with an intrinsic motivation to do something do so for their own sake, rather than social coercion or expectation of reward.

Kemala (2014) in her research conclude that in every subject, motivation, environment, task, teacher and material are important roles in making students autonomous learners. Lengkanawati (2017), for the perspective of psychological provides a view of how some factors for example, age, learner autonomy that they use itself, can be as motivation aspects and self-evaluation for the students to interact with others.

In these researches, they are focused on learner autonomy and motivation in different situation. Therefore, this study investigates the activities and aspects that motivate the post-graduate student in overseas university to become 
autonomous learner. In addition, this study explores the explanation of the motivation behind autonomous learner.

\section{LITERATURE REVIEW}

\section{Learner Autonomy}

Learner autonomy is the responsibility of the learner for their own learning. It such aspects of the learning process that is also a goal setting consist of selecting course content as well as appropriate methods, techniques, and strategies; monitoring the learning process and appraising all that has been learnt (Cirocki, 2016).

\section{Characteristics of Autonomous Learner}

Some previous discussions have summed up that autonomous learners are individuals who interested in seeking learning opportunities in their learning process for themselves rather than being guided by the teacher. Regarding the characteristic of autonomous learner, Yamashita (2015) points out four aspects about autonomous learner; a) learners should describe what is happening, or what was learned in their classes. When learning English, for example, an autonomous learner may think about the relationship between the new grammar in what he learned today and the grammar he learned earlier. b) the autonomous learner can formulate his own learning goals, but those goals are parallel or even close to the goals of his teacher. c) autonomous learner can choose acceptable learning strategies and implement those strategies. For example, in reading practices, autonomous learners will go through the text to see what is available in the text, such as images, graphs, names, subtitles, etc., rather than simply trying to read and understand it. d) Autonomous learners can track and make necessary adjustments to the effectiveness of their use of strategies. An autonomous learner, for example, may first try to find out which frameworks and points he does not understand and then try to find the other effective ways to respond to them.

\section{Motivation}

Motivation has been described as the learning engine and can influence what, when, how and if we choose to learn, and is a major performance factor (Liu, 2015). The correlation between autonomy and motivation from a new perspective indicates an increase in the motivation of the learner to take responsibility for his own learning (Benson, 2013). The connection between autonomy and motivation from new perspective suggest an enhance motivation which conducted by the learner to take responsibility for himself learning. It means that motivation precedes autonomy, especially the motivation which dominant connected the meaning of identification learners and his learning. 
As developing by León, et.al (2015), this study which conducted research in the field of autonomy and motivation. Then, It has become a notion of selfmotivation that is largely based on theory of self-determination and has become a key factor in autonomy

\section{Motivation in Foreign Language Learning}

Motivation has been described as the learning engine and can influence what, when, how and if we choose to learn, and is a major performance factor (Liu,2015). Motivation is seen as an important part or factor in the learning process (Suryasa, et.al, 2017). Learning and motivation are of equal importance to doing something. Motivation drives us through learning processes and helps us to gain new knowledge and skills while learning. Besides, motivation is generally characterized as the attitude of the learner with a view to achieving the learning objective. As one of language learner's psychological factors, Motivation was agreed by all individuals, especially English teachers and researchers, who are primarily responsible for initiating English as second foreign language learning. Motivation is also primary source contributing to individual language learning Bravo, et.al (2017).. But people with the greatest talents can't achieve long-term goals without adequate motivation. Language learner will think positively about his own learning because of their encouragement.

\section{The Roles of Motivation in Fostering Learner Autonomy}

Compared with extrinsic motivation, intrinsic motivation helps learners to enjoy long-term learning and encourages the ability of learners to learn autonomously. In Harmer's perception, for most research methodologists, intrinsic motivation derived from within the person is especially important in promoting student performance in L2 learning. Wulf, et.al (2016) the relationship between the forms of motivation for the students and the technique used was examined. He found that students who were more intrinsically motivated tended to use different learning methods relative to students who were less intrinsically motivated. Ryan, et.al (2016) said that findings from various experimental studies suggest that intrinsic motivation is more critical than extrinsic motivation to boost the learning spirit of the learner. Besides, its fundamental principles are based on the assumption that people are interested in need of autonomy and an inherent curiosity Ryan, et.al (2016). Intrinsic motivation is correlated with a greater interest of learners in learning material and higher academic achievement, and typically improves learning experience. It is fair for intrinsically motivated learners to be willing to be involved in learning without outside awards. Nicholson (2013) states intrinsic motivation when learners actively seek out and take part in activities without being rewarded with materials outside the learning 
task. Looking at this situation, it is assumed that intrinsic motivation will encourage students to become autonomous learners.

Extrinsic motivation is desire to perform because of attaining a certain reward or goal. It is known as extrinsic motivation when the motive for doing something is to get something, not just the task itself, e.g. passing an exam, getting paid, etc(Kim, et.al, 2015). In other words, student who are extrinsically motivated act and do affairs as he guests that what he do will causes fortunate results like a reward, teacher appreciation or teacher approval, getting good grades, stickers, avoid some punishment (Anjomshoa\&Sadighi, 2015).

\section{RESEARCH METHOD}

The design of this research is qualitative. The reason why this research is engaged with qualitative method study is that the researcher wants to obtain the detailed information about what have been gained from the data. For this research purpose, it refers to do interview with the subject to get the detailed information about his motivation for being an autonomous learner. In this section, the researcher makes a schedule that is matched with subject's time, then the researcher asking some questions that relates to what the information needed in this research.

The study takes place in overseas university (Australia). The situation of the learner autonomy in his place of study focuses on builds the students as autonomous learner. The subject of this research is a post graduate student who takes his study in overseas university in Australia. The subject is chosen based on the considerations that the student has been studying in overseas a year and half with his high achievement. The subjects' takes master degree and the major in his study is Master of TESOL. He is mastery in education field which focuses on student in high school. He is also a good student who joins a lot of activities in his university which focused on EFL and ESL. It is assumed that he has enough experiences as a student or autonomous learner in overseas university.

Interview uses to gather the data from the subject about his motivation, feelings, thoughts, and views in positive condition as an autonomous learner. The main points for asking the student is his motivation (intrinsic and extrinsic) become autonomous learner. The researcher uses semi-structured interview in collecting the data through interview which can modify by the researcher about the format or questions based on the situation in interviewing process. It is because the researcher wants to formulate the list of the questions before conduct the interview. There are 10 questions which are given by the researcher to the subject of this research. The question (1-4) deals with the student's activities, then, questions (5-10) deals with the student's motivation during his study in overseas university as an autonomous learner. 
The researcher is doing interview through learner about his motivation in develop himself to become autonomous learner. In this action, mobile phone is used by the researcher as the device to record all the students' response. This data is to answer the research question that wants to know the student's motivation for being autonomous learner.

Before analyzing the interview, the researcher transcribed the interview from the recording. Transcription of interviews is necessary because it helps researchers to become aware of interesting points raised by interviewees. Furthermore, because the interview was conducted in Bahasa Indonesia and English, any relevant thoughts emerging from the comments of the interviewee were translated into English so that they could be recorded in the results of the study. A colleague also reviewed the translation to ensure the words were in line with the statements of the participants. The researcher will employ pattern coding in order to make the classification of data gathered in the study and present them based on developed themes or constructs. After that, the researcher will represent the two research questions by using description and explain all the results of the data by describing it in detail. The data analyze by reducing the data first and relating into literature review and theory to discard the irrelevant data. Then, the researcher organize also compress the data into data display. Finally, the researcher will carefully analyze and interpreted in the Findings and Discussion section.

\section{FINDINGS}

This part is exploring the finding of collecting the data. It is closely related to the way the overseas university student motivate himself for being an autonomous learner. From some questions in interview section, these are the focus answer that is matched with the aspect that the researcher need.

\section{Students' Method in Learning Language}

In this section, the subject has explained about his method to study in comfortable situation. He is also said that in everyday activities, he also makes evaluation what happen in that day.

He explains as follows:

\section{Excerpt 1}

S: Perfect learning environment for me is when I can focus with my own. I did discussion with my friends but I did my task and studied prefer as independent.

\section{Excerpt 2}

S:I always evaluates what I did in that day. Before I do so many activities in a day, I make a plan for anything. I always discipline with my plan 
especially in learning language. In the end of day I evaluate all the things done. What I plan and what I get should be in line. If it is not, I should change the method to still get the goal of the day in the next day. It is part of my own responsibility as student and it works for my study.

\section{Excerpt 3}

S: I join some activities like charity, campus event, side job as translator, and also freelance worker in market. I did it to enjoy my day beside study. But I still stand in my goal as a good student in my campus. I make it all the things happen balanced.

\section{Students' Motivation for being An Autonomous Learner}

In this part, the subject explains about the motivation as an autonomous learner in overseas university. Some questions are related to this part, but the answer that can explain more about his motivation is in this section.

He explains as follows:

\section{Excerpt 4}

S: when I get bored with all the activities in learning language, I go somewhere which peace for me like park and beach. But actually, the main thing that helps me to kill my boredom is calling my parents. They are my biggest support system for me as an overseas university student.

\section{Excerpt 5}

S: I know that is not easy being an overseas student. When I give up, I always remember what my dream which bring me here.

\section{Excerpt 6}

S: I want to be a good teacher for my student in Indonesia. I will do my best for them; give them a new knowledge, a new story to keep their dream likes me study in overseas university. I want to upgrade my level in my job. Those are the reasons why I should finish my study on time or as soon as possible.

\section{DISCUSSION}

\section{Students' Method in Learning Language}

This section explores student's method in learning language to address the students as autonomous learner or not. Generally, from interview data the researcher can conclude that this student is an autonomous learner. It is because of his method of learning, his goal, and his discipline in learning language. He explains as follows: 


\section{Excerpt 1}

S: Perfect learning environment for me is when I can focus with my own. I did discussion with my friends but I did my task and studied prefer as independent.

From this explanation he called as an autonomous learner because he prefers to study by himself. Additionally he also give another explanation as follow:

\section{Excerpt 2}

S:I always evaluates what I did in that day. Before I do so many activities in a day, I make a plan for anything. I always discipline with my plan especially in learning language. In the end of day I evaluate all the things done. What I plan and what I get should be in line. If it is not, I should change the method to still get the goal of the day in the next day. It is part of my own responsibility as student and it works for my study.

In this additional explanation, it shows that he is a discipline student especially in his study. Besides learning language in overseas university, he also has a lot of activities as translator, host, freelance worker and charity volunteer. He mention in this explanation:

\section{Excerpt 3}

S: I join some activities like charity, campus event, side job as translator, and also freelance worker in market. I did it to enjoy my day beside study. But I still stand in my goal as a good student in my campus. I make it all the things happen balanced.

With all the explanation above, the researchers conclude that he is an autonomous learner which has a lot of activities.

Based on the students' responses, it appears that this student can call as an autonomous learner. Autonomous learner is capable of formulating his own learning objectives and autonomous learner is able to select and implement appropriate learning strategies Ertürk, (2016). Further, based on excerpts, this student has characteristic as autonomous learner, autonomous learner can monitor the effectiveness of their use of strategies and make necessary changes for them. he always being discipline in his study although he has a lot of things to do.

\section{Students' Motivation for being An Autonomous Learner}

This section is completely explains the motivation behind this student. It is also relates to the research question which asking about the motivation from this student. He argued about the way to kill his boredom as follows: 


\section{Excerpt 4}

S: when I get bored with all the activities in learning language, I go somewhere which peace for me like park and beach. But actually, the main thing that helps me to kill my boredom is calling my parents. They are my biggest support system for me as an overseas university student.

From that, we know that the student is similar to other students. He gets boredom like others, but he is not give up with that because he has his own way to kill the boredom. He is also explains what actually did when he gives up:

\section{Excerpt 5}

S: I know that is not easy being an overseas student. When I give up, I always remember what my dream which bring me here.

In that explanation, the student tries to stand in his dream until he got finish. He has a good effort to do that. He motivates himself in any aspect. He wants to be a good teacher for his students in Indonesia when he is back, he mention the explanation as follows:

\section{Excerpt 6}

S: I want to be a good teacher for my student in Indonesia. I will do my best for them; give them a new knowledge, a new story to keep their dream likes me study in overseas university. I want to upgrade my level in my job. Those are the reasons why I should finish my study on time or as soon as possible.

He builds his motivation from other aspects to makes his goal achieved. From those excerpt, the researcher conclude that this student has a good motivation as an autonomous learner. From the theories above, this student has intrinsic and extrinsic motivation.

Students who have intrinsic motivation are willing to stay with intricate and complicated problems and gain knowledge from their slips and mistakes Ryan, et.al (2016). From excerpt 5 it can groups as intrinsic motivation. He gives solution for his own; he explores his ideas and learning new thing because of his own curiosity. He always feel enjoy when he did a lot of activities in learning language.

Besides that, this student is also has extrinsic motivation for being an autonomous learner in learning language. Extrinsic motivation is motivation to perform due to achieving a certain reward or target Wulf, et.al (2016). When they are doing something is to get something like passing exam, being paid, etc(Anjomshoa, L., \&Sadighi, F. 2015). From excerpt 6, the researcher knows that extrinsic motivation is also happen in this student. He wants to get another goal to be a good teacher for his students in Indonesia. It can infer that he wants to get better salary after he finishes his study. He graduates from an overseas university, which all of people in Indonesia known this is good university. 


\section{CONCLUSION}

This study explores an Indonesian post graduate student who studies in overseas university with his own motivation as an autonomous learner in learning language. From the data interview, this student categorize as an autonomous learner because he has their own responsibility in his study and his goal. He makes a plan everyday what actually have to do. In the end of the day, he evaluates what actually did in that day. If there is a plan which is not done by him, he changes his method for getting better in the next day especially in learning language.Besides that, he is also joining a lot of activities in his campus and side jobs.

From that, the researcher conclude that this student challenge himself for being a good autonomous learner. That explanation makes the researcher understand what makes the students motivate for being autonomous learner. He has intrinsic and extrinsic motivation. In case of intrinsic, he gives solution for his own; he explores his ideas and learning new thing because of his own curiosity. He always feel enjoy when he did a lot of activities in learning language. Then, in case of extrinsic, he wants to get another goal to be a good teacher for his students in Indonesia. It can infer that he wants to get better salary after he finishes his study.In conclusion, this study will enrich the discussion which relates to students' motivation for being an autonomous learner especially in overseas university.

\section{REFERENCES}

Abuhamdeh, S., Csikszentmihalyi, M., \& Jalal, B. (2015). Enjoying the possibility of defeat: Outcome uncertainty, suspense, and intrinsic motivation. Motivation and Emotion, 39(1), 1-10

Anjomshoa, L., \&Sadighi, F. (2015).The importance of motivation in second language acquisition. International Journal on Studies in English Language and Literature (IJSELL), 3(2), 126-137.

Blidi, S. (2017). Collaborative Learner Autonomy. Singapore:Springer

Benson, P. (2013). Teaching and researching: Autonomy in language learning. London, Routledge.

Bravo, J. C., Intriago, E. A., HolguĆn, J. V., Garzon, G. M., \&Arcia, L. O. (2017). Motivation and Autonomy in Learning English as Foreign Language: A Case Study of Ecuadorian College Students. English Language Teaching, 10(2), 100-113.

Cirocki, A. (2016). Developing Learner Autonomy through Tasks: Theory, Research. Practice.

Ertürk, N. O. (2016). Language learner autonomy: Is it really possible? ProcediaSocial and Behavioral Sciences, 232, 650-654.

Kemala, Z. (2014). An analysis of autonomous learning strategies used by senior high school students (Doctoral dissertation, Universitas Pendidikan Indonesia). 
Kim, D. H., Wang, C., Ahn, H. S., \& Bong, M. (2015). English language learners' self-efficacy profiles and relationship with self-regulated learning strategies. Elsevier-Learning and Individual Differences, 38, 136-142.

León, J., Núñez, J. L., \& Liew, J. (2015). Self-determination and STEM education: Effects of autonomy, motivation, and self-regulated learning on high school math achievement. Elsevier- Learning and Individual Differences, 43(2), 156-163.

Liu, Hui-ju. (2015). Learner autonomy: The role of motivation in foreign language learning. Journal of Language Teaching and Research 6,. 6(2), 1165-1174.

Lengkanawati, N. S. (2017). Learner autonomy in the Indonesian EFL settings. Indonesian Journal of Applied Linguistics, 6(2), 222-231.

Ryan, R. M., Deci, E. L., \& Vansteenkiste, M. (2016). Autonomy and autonomy disturbances in self-development and psychopathology: Research on motivation, attachment, and clinical process. Developmental psychopathology, 1(2),1-54.

Suryasa, W., Prayoga, I. G. P. A., \& Werdistira, I. (2017). An analysis of students motivation toward English learning as second language among students in Pritchard English academy (PEACE). International journal of social sciences and humanities, 1(2), 43-50.

Wulf, G., \& Lewthwaite, R. (2016).Optimizing performance through intrinsic motivation and attention for learning: The OPTIMAL theory of motor learning. Psychonomic bulletin \& review, 23(5), 1382-1414.

Yamashita, H. (2015). Affect and the Development of Learner Autonomy through Advising. Studies in Self-Access Learning Journal, 6(1), 62-85. 